\title{
Unpacking Sexual Embodiment and Embodied Resistance
}

\author{
Breanne Fahs and Eric Swank
}

\subsection{Introduction}

Understanding the body and its relationship to the social world has long fascinated and perplexed social scientists, natural scientists, feminist theorists, and historians alike. At a basic level, there is no society without bodies. The body serves as a fluid and permeable boundary between our individual selves and the outside world, and has great significance to how we see our identities, our sexualities, and our relationships with others. Grounded in a history of dichotomizing the mind and body and largely ignoring the body outside of its pesky role in inspiring madness and mental illness (Thompson 1999), the body has been historically overlooked by Western scholars; in fact, the notion of embodiment has entered sociological and psychological conversations only quite recently.

Shockingly little social science work has interrogated, until the last 20 years, the role of the body, its impact on gendered relations, and its paramount importance to the study of social inequalities. We know far more about the body as a medical enterprise, a collection of parts and processes, than we do about its social and sexual

B. Fahs $(\bowtie)$

Women and Gender Studies Program, Arizona State University, Glendale, AZ, 85306 USA

e-mail: Breanne.Fahs@asu.edu

E. Swank

Arizona State University, 85306 Glendale, AZ, USA

e-mail: eric.swank@asu.edu functioning. The study of the social concept of embodiment showcases the tense relationship that the body has to its biological and social contexts, particularly as the body connects to sexual feelings, thoughts, and actions (Attwood 2007; Coy and Garner 2012). Further, because embodiment theories and research are grounded in such social contexts, much of the work around embodiment has (both overtly and subtly) a political emphasis. Bodies not only exist, but interact, and as such, social processes, biases, and emotions are written onto the stories of embodiment.

This chapter traces the key conflicts and debates around defining and measuring embodiment, followed by a multifaceted discussion of how different disciplines and scholarly traditions have theorized and studied embodiment. We subsequently review how embodiment has been conceptualized over the lifespan (e.g., childhood, adolescence, adulthood, and old age), followed by a review of the scholarly work on sexual performance and embodiment (e.g., body parts, enhancing the body, exercise, and orgasm). The chapter concludes with a discussion of embodiment as it relates to social identities like LGBT identity, race, gender, and class, followed by a discussion of embodied resistance, or how people with stigmatized bodies fight back, imagine bodies outside of the norm, transform the idea of a "freak," or map on political philosophies like anarchism to the study of embodiment. 


\subsection{Part 1: What is Embodiment?}

Embodiment refers to the experience of living in, perceiving, and experiencing the world from the physical and material place of our bodies. More precisely, embodiment researchers have studied embodiment as the process of "being embodied" and as the process of "embodying the social," with both conceptualizations overlapping and at times occurring simultaneously (Crossley 1996; Rubin 1984). "Being embodied" refers to the lived embodiment experiences of being in our bodies, having corporeality, and existing in actual skin (Grosz 1994; Young 1990).

Some theorists have theorized the body not as a passive entity in need of cognitions to make sense of the world, but as something capable of genuine experience, that is, having "latent knowledge" (Merleau-Ponty 1945, p. 238). Subjective experiences of the body may occur outside of the cognitions we impose onto our bodies (Young 1990), as we simultaneously embody both an objectified and material self and an experiencing and subjective self (Fahs 2011a). Other embodiment theorists have also suggested that the body can exist through "intersubjectivity" (or shared understandings of reality) or relationships to other people. Within a sexual exchange, for example, people can experience their own bodies and the bodies of another simultaneously as objects and subjects, desiring and being desired (Cahill 2011). This immense theoretical complexity leaves wide open terrain for critical scholars and social scientists to study, measure, and define embodiment.

\subsubsection{Key Conflicts and Issues}

Theorists and researchers often start with different premises of what constitutes a body and how to understand and theorize the body as it exists in social space. As a key conflict in the theorizing about embodiment, essentialist theorists (that is, those who argue that the body has a biological and scientific reality that is not shaped and contested by social forces) and the social constructionists (those who argue that social and historical contexts influence and impact our bodies) have disagreed about how to understand the body and embodiment (DeLamater and Hyde 1998). Studying sexuality was, for Masters and Johnson (1966), a biological project that looked at the sexual functioning of biological parts outside of a social context. While some recent work in the natural sciences has looked critically at biological understandings of sexuality (Lloyd 2009), most biological research on sexuality ignores both subjectivity and people's own understandings of their embodied sexual experiences (Fahs 2011a).

Social constructionists, on the other hand, understood sexual desire, identities, experiences, and relationships as fundamentally social and dependent on interpretive processes (Plante 2006; Tiefer 2006). Bodies do not have any inherent meanings, but social context and social messages around bodies are created by social interactions of people in specific social situations (e.g., bodies have different meanings and expectations in synagogues, police stations, barber shops, and grocery stores). By saying that people's understandings of bodies are fluid, this does not mean that people simply choose their definitions of the social forces that dictate, discipline, and control bodies (Bartky 1990; Foucault 1978) and how bodily experiences and feelings relate to the (gendered, racialized) social world (Bordo 1993; Young 1990). Rather, people must make sense of the social world as they either internalize or resist the bodily expectations directed at them. Other cultural studies theorists have focused more on how bodies are produced or performed, both consciously and unconsciously, and how embodiment can be "inscribed" for specific people or specific social contexts (Butler 1990). As spinoffs of this, theories of embodiment as related to visible identities (Alcoff 2005), imagined spaces (Gatens 1996), and cyborg or technologically-inscribed bodies (Haraway 1991) have also emerged in recent years. 


\subsubsection{The Trouble with Defining Embodiment}

Building on the conflicts between essentialists and social constructionists, embodiment also has permeable boundaries in terms of what, exactly, it encompasses. Embodiment includes a wide range of topics, identities, and approaches, including areas as vast as medicalization of bodies (Braun 2005), the racialization of bodies (Hill Collins 1990), the aging body (Hillyer 1998), the fat body (Rothblum and Solovay 2009), the disabled body (Inckle 2014), bodily privilege (Bobel and Kwan 2011), the sexual body (Hannabach 2007), the intersexed or trans body (Williams et al. 2013), and the gendering of bodies (Braun 2005; Tiefer 2008), among others. The definitions of embodiment, then, shift in relation to the sorts of approaches employed to "know" or "understand" embodiment.

\subsubsection{Methodological Conflicts to Studying and Measuring Embodiment}

Struggles about conflicts over embodiment appear most vividly in the methodologies employed to study and understand embodiment. A range of disciplines have worked to unpack and understand embodiment, including critical psychology, sociology, gender studies, queer theory, sexuality studies, rhetoric and literary studies, geography, social theory, and cultural/media studies. One recent methodological review of embodiment research identified some emergent traditions in embodiment work: social theories of the body; histories of the body; analyses of bodily techniques; and studies of embodied experience (Brown et al. 2011).

Primarily understood as an abstract construct, embodiment has appeared most often within the theoretical literatures rather than empirical ones. For example, Michel Foucault's (1977) highly influential work on bodies and embodiment posited that institutional and state power is exercised onto bodies both by force and, more insidiously, through compliance and internalized oppression.
The actual need for discipline and control waned in the face of people's sense that they should keep their bodies and sexualities in control (i.e., "self-surveillance"), thus revealing the chaotic and complicated workings of power as more of a "web" than an act of simple dominance over the powerless. Pierre Bourdieu's (1977) work also similarly fused sociological and anthropological theories of embodiment by emphasizing how taste and disposition are written onto the body. Many theorists have worked to "bring the body back in" via social theorizing around the body (Shilling 2004).

Historical accounts of the body have also worked to incorporate new narratives about how the body has previously existed, and how that relates to the current status of bodies and embodiment. Whether analyzing the histories of sexuality and masturbation (Laqueur 2003), the relationship between language and sexuality (Foucault 1984), or the missing histories of bodily desire and subjectivity (Smith-Rosenberg 1986), historians have unpacked embodiment retrospectively. The histories of embodiment and the uses of the body as a weapon of oppression or empowerment have long haunted historical narratives of embodied lives (Foucault 1977; Thompson 1999).

Methodologies of embodiment have also explored specific bodily practices and performances, looking at subjects as wide reaching as tattoos (Pitts 2003), crying and tearfulness (Hepburn 2006), dizziness (Brown et al. 2011), anorexia and eating disorders (Bordo 1993), cosmetic surgery (Heyes 2007), breast feeding (Schmied and Lupton 2001) and walking (Young 2005b). Studies using video diaries and surveillance of the body (that is, recording its sounds, movements, shapes) have documented the body audibly and viscerally (Bates 2013).

When conceptualized within the framework of sociological and psychological work, embodiment has emphasized the importance of studying subjectivities. How to methodologically engage with embodied feelings, sensations, and engagements with the world from this perspective has produced multiple methodologies for embodiment within the social sciences (Brown et al. 
2011). Some empirical research on embodiment, for example, has focused on sweating, pain, and aging (Gillies et al. 2004), while others have focused on discursive accounts of subjectivity (Morgan 2005). In these accounts, the body's "fleshy," desirous, difficult characteristics are emphasized in relation to cognitive processes (Rohrer 2007), though this work also emphasizes emotional experiences and "embodied subjectivity" (Probyn 1993).

Psychology, in particular has had a disjointed relationship with embodiment, seeing it initially as an abstract entity conceptualized only through notions of stimulus-response, reflexes, habits, drives, and behavior; this reading largely neglected social interaction, complex social reasoning, bodily subjectivities, and desires (Glenberg 2010). Methodological disagreements have ensued about the optimal ways to study and measure embodiment. Some social scientists use positivistic approaches to explain people's relationship to body image (Jones 2001), body objectification (Noll and Fredrickson 1998), racial biases (Hunter 2002), and hair removal practices (Martins et al. 2008). Others argue that grounded theory and interpretive phenomenological analysis, which analyzes participants' accounts of their bodies by allowing categories to emerge from the data, constitutes the best way to engage with embodiment (Braun and Clarke 2006; Tolman 2002). However, to date, psychologists have drifted to deductive and quantitative approaches while most of the other social sciences have mostly foregone quantitative studies as they argue for the advantages of using grounded theory. These inductive methods subvert mechanical understandings of causation and correlation, and they challenge the overly reductive tendencies of psychology to characterize participants within pre-generated frames (Tolman 1994).

As another approach to studying embodiment, some researchers posit that people cannot derive knowledge from the body without actually involving their body in the psychological research. These techniques emphasize the moving, living, breathing body as it relates to understanding and self-awareness. For example, memory workwhere researchers focus on the body as "being in" rather than "thinking about" experiences, often by using trigger words - constitutes another approach to studying embodied subjectivity (Gillies et al. 2004). Embodiment researchers have also empirically examined holding objects (Niedenthal et al. 2001), head movements (Foster and Stack 1996), and "implicit attitude experiments" (Foroni and Semin 2012) to measure different kinds of embodied experiences.

\subsection{Part 2: Theorizing Embodiment}

\subsubsection{Who Gets to Decide What is "Embodied" or Not?}

Embedded within discussion about embodiment are several key tensions about the notion of assessing embodied experience. For example, some theorists have discussed embodiment as an awareness of embodied experiences (Millsted and Frith 2003). Others have described embodiment in more complicated terms, constructing embodiment as an ongoing negotiation of agency, empowerment, and bodily autonomy (Earle 2003). Much like discussions of "agency" within the feminist literatures (Albanesi 2009), conflicts about how to measure, define, and assess participants' embodied experiences persist throughout the literature.

\subsubsection{Feminist Contributions to Embodiment}

Given that women's worth and meaning have often revolved around appraisals of their attractive or "ugly" bodies, while men's value has been linked more to their minds or functional bodies, feminist theorists have had to grapple with this painful history without neglecting the importance of the body (Grosz 1994). They have argued that the body must be considered in its material, corporeal form while also examining the body as a product of social forces (Irigaray 1985). Rather than separating the body and mind, many argued that the mind and body are inextricably linked together (Grosz 2008). 
Feminist theorists have been particularly skilled at describing the impositions of patriarchal culture onto bodies, especially women's bodies. Several feminist theorists have used gender and sexuality as markers of institutionalized heterosexuality, theorizing how bodies perform (or are expected, by male audiences and authority figures, to perform) in particular ways (Bartky 1990; Bordo 1993; Butler 1990). French feminist theorists like Luce Irigaray (1985) and Monique Wittig (1992) theorized the body and embodiment as a product of systems that promote capitalism, value masculinity and patriarchy, and subject women to multiple intrusions and oppressions.

As one of the key contributions of feminist theory to the study of embodiment, feminists argued for intersectional approaches to studying embodiment. Specifically, feminists urged a consideration how social identities like race, class, sexuality, ability, size, and age all intersected with gender and were projected onto the body (Collins 1999). For example, the experience of poverty presents not only economic challenges, but writes itself into how people eat, dress, bathe, work, and live. Corporeality, then, was situated within and constructed around interlocking and multiple forms of oppression, and embodiment provided a way to understand social differences as experienced through (and on) the body (Grosz 1994).

Postcolonial feminist scholars have also taken up notions of embodiment in order to map the experiences of the colonial subject (Minh-Ha 1989; Spivak 1999). With accusations that people of color were "closer to nature," postcolonial feminist theorists have deconstructed and undone some of the damage done by such claims through their embodiment research (Minh-Ha 1989; Spivak 1999). Postcolonial scholars have also challenged hierarchies of power embedded within racialized, sexualized, classed, and gendered dynamics, both within the United States and globally (Morris 2010).

Feminist theorists have also taken up the ways that cultural scripts and norms get imposed onto bodies, forcing them into binaries of female/ male and feminine/masculine (Bordo 1993). By examining topics like exercise, dieting, makeup, cosmetic surgery, vaginal "rejuvenation," body hair, and other sites of bodily discipline, feminists have marked the production of femininity and masculinity through the body (Bordo 1993; Chrisler 2012; Fahs 2011b; Weitz 2001). Feminists have also theorized about the shaming of women's bodies; emphases on changing physical appearance via hair straightening for women of color (Hill Collins 1990), surgical reconstruction of noses (Eriksen and Goering 2011), or the compulsive elimination of body hair for women (Fahs 2014) present one mode of doing so. Similarly, shame directed toward women's natural bodily processes also occurs as in discourses of menstrual shame (Bobel 2006). Clearly, women grapple with numerous disciplinary practices that control the presentation of gender, race, class, and sexuality.

\subsubsection{Queer Contributions to Embodiment}

Queer theorists have also contributed to the study of embodiment, primarily by critically examining the ways that heterosexuality has been produced, institutionalized, and valued above all other forms of sexual identity and expression (Butler 1990; Sedgwick 1990). Queer theory focuses not only on eliminating the binary between heterosexual and homosexual, but also challenging all dominant narratives that produce "normative" bodies and "normative" bodily expression (Warner and Berlant 2000; Butler 1990). By critiquing the construction of "normal" behaviors, practices, and bodies, queer theorists have interrogated the meanings of the more literal aspects of queer life (e.g., butch and drag performances, gay pride parades) but also the more metaphorical and abstract ways of seeing and doing sexuality (e.g., "queering" literature).

Most queer and feminist theorists have been criticized for not addressing corporeal embodiment more closely (that is, the lived experiences of being in a body) (Braidotti 1994; Grosz 2008). By theorizing the discursive production of embodiment, however, queer theorists have worked 
to upend categories, binaries, and dichotomies that constrain sexuality and gender (Halberstam 1998), emphasizing instead the marginalized or demonized embodied practices and the systems that regulate and control bodies and sexualities (Butler 1990). Particular attention has been paid to those who violate social norms, including feminine men (Connell 2005), masculine women (Halberstam 1998), transgendered people (Feinberg 1996; Stryker 1994), fat bodies (Rothblum and Solovay 2009), and those occupying multiple social locations at once (Grollman 2012; Meyer et al. 2008; Slevin and Linneman 2010).

\subsection{Part 3: The Body Becoming Sexual Throughout the Lifespan}

\subsubsection{Childhood}

Studies of childhood and sexuality generally come from a "social problems" perspective; as such, embodiment and sexuality research on childhood generally has focused less on sexuality as a developmentally normal occurrence and more often on sexual abuse (Bancroft 2003; Ryan 2000), the production of heteronormativity (Renold 2005), sexual behaviors that children engage in (Friedrich 2003), and retrospective accounts of people's childhoods (Graham 2003). Not fully constructed as "embodied citizens," most research has focused on how children's bodies and sexualities are understood within a discourse about "innocence," virginity, and the danger of adult appropriation of childhood sexuality, (which can lead to a moral panic) (Fahs et al. 2013; Robinson 2012). Language about sexuality, in particular, plays a key role in shaping children's understandings of their sexuality and their bodies as foreign, scary, and dangerous (Lamb and Coakley 1993).

Most often, children's sexualities and bodies are constructed as immature entities that "evolve" into adult sexuality later on (e.g., "emerging sexualities"), as childhood expressions of sexuality are often seen as playful or as a marker of abuse rather than desirous and "sexual" per se (Hyde 2003; Renold 2005; Robinson 2012). Girls’ play in their cross-gender friendships sometimes signals a shift between "innocence" and sexuality (Hauge 2009), though debates still ensue about how to draw the line between the sexual and the nonsexual for children. Children of both genders clearly identified genitals as exciting, private, and pleasant (Rademakers et al. 2003), and clearly masturbated during childhood (Strachan and Staples 2012). One well-known study by Herdt and McClintock (2000) identified the "magical age of ten," where distinctly sexual feelings emerge and a shift occurs from prepubescence to adolescence. Still, little research has explored what sexual meanings children derive from their bodies, as children's embodiment is almost completely ignored.

\subsubsection{Adolescence}

Compared to research on childhood embodiment, far more work has examined adolescent embodiment and sexuality, particularly around subjective perspectives of "losing" virginity and first sexual experiences (Loewenson et al. 2004). Studies on adolescent boys often deal with processes that mark a transition into manhood, particularly talking about the sexual appeal of girls and women (Thorne 1993), unsolicited touching of girls and women (Renold 2007), seeking muscularity (McCreary and Sasse 2000), and fighting with other boys (Messerchmidt 2000). Notably, the commonplace focus on girls' sexual experiences assumes that girls either do not act or do not have sexual desires while adolescent boys' sexual desire is assumed to be always already present (Fine 1988; Tolman 2002). Further, assumptions of heterosexuality and the impositions of heterosexism appear in full force during adolescence, inscribing only heterosexual embodiment as valuable and desirable for much of adolescence (Hauge 2009; Renold and Ringrose 2011; Tolman 2002).

Some research on adolescent embodiment has asked girls and boys to contextualize and give meaning to their sexual experiences and to their bodies, particularly within heterosexual relationships (Impett et al. 2011). Many adolescents re- 
ported feeling disembodied during their sexual experiences, looking instead to fashion, diet, and denial of the senses to construct the adolescent body (Tolman 2002; Holland et al. 1994). Further, many adolescent girls also struggled with the fear of sexual violence (or actual experiences of sexual coercion) alongside negative reputational risks of expressing sexual desire (Tolman 2002). Along these lines, adolescent girls often felt pressured to meet boys' expectations for sexuality; consequently, many adolescent girls reported faking orgasm or submitting themselves to patriarchal surveillance (Tolman 1994, 2002). Still, other adolescents were able to fight back against both heterosexism and patriarchy by feeling that they had sexual agency or acknowledging the ambivalent meanings of sexuality at their age (Gleeson and Frith 2004; Hauge 2009).

Adolescent sexuality also differed across identity categories, as urban Black and Latina girls' had to negotiate assumptions about hypersexuality and fatness while suburban white girls dealt with the assumption that they lacked sexual desire and were anorexic (Boyd et al. 2011; Le Espiritu 2001; Tolman 2002). The tension between pleasure and coercion informed adolescent girls' sexuality in many ways, particularly in the U.S., as girls' sexual desire remained largely missing within sex education (Fine and McClelland 2006; see also Fields, Gilbert and Miller, this volume). For example, U.S. teen pregnancy rates remain much higher than rates in other Western countries because of the combination of wider economic inequalities, greater gender traditionalism, and social policies that fail to see contraception as a right for young women (Lottes 2002; Singh et al. 2001). Further, international studies about girls' sexuality have shown complicated dynamics for girls as they negotiate "innocence" and sexuality (Curtis 2009; Schalet 2010).

Cultural and social scripts of sexuality have also influenced adolescent embodiment and sexuality, particularly around the performances of heterosexuality and bisexuality (Pascoe 2005) and the search for the "perfect body" and perfect masculinity/femininity via cosmetic surgery. In the past, compulsory heterosexuality manifested as the constant push toward all young people declaring themselves as solely heterosexual, but sexual scripts have been becoming more liberal in the last several decades. Specifically, sexual fluidity (Diamond 2008) and "performative bisexuality" (Fahs 2009) have encouraged young women to explore experiences outside of heterosexuality, though many of these are still couched as ways to please boys and men (Fahs 2011a). For adolescent boys, studies suggest more fixed and stable identities around sexual desire and greater pressures to perform heterosexuality at all times (Kimmel 2004). Ironically, despite having more access to sexual diversity, cultural and social scripts about sexuality, condoms and contraception, and pornography, adolescents still reported much uncertainty and pain about negotiating their sexuality and embodiment (Fine and McClelland 2006; Holland and Thomson 2010).

\subsubsection{Adulthood}

Research on adult embodiment and sexuality has focused far more on notions of satisfaction, pleasure, entitlement, wantingness, and relationships compared to studies of adolescents (Fahs 2011a; McClelland 2010, 2014). For women, satisfaction with body image and increased sexual desire occur in mid-life as women age (Woertman and Brink 2012), though experiences with body shame and sexual trauma (by adulthood, a more common occurrence) can also lead to feelings of disembodiment and sexual dissatisfaction for women (Sanchez and Kiefer 2007; Young 1990). Research emphases on sexual satisfaction has also led to controversies about how to measure and assess people's sexual satisfaction, especially for oppressed people (McClelland 2014).

"Controlling images" promoted through the media, schools, families, and in the broader culture also influence not only how women experience their bodies and sexualities but also how they experience sexual desire and pleasure. For women of color, "controlling images" can infuse their embodiment with stereotypes about promiscuity and sexual "deviance" (Hill Collins 1990; Zavella 2008). For fat women, stereotypes about laziness, moral inferiority, and "gross" bod- 
ies can also lead to feelings of inadequacy and distress (Bessenoff and Snow 2006). Similarly, for disabled women, stereotypes of frailty and limited bodily control can impact how disabled people feel about their bodies and sexualities (Hassouneh-Phillips and McNeff 2005; Shildrick 2005).

Women in general also face pressures to contain and manage their unruly bodies throughout adulthood. Containment of menstruation, hiding menstrual products, and managing menstrual "odors" are all imposed upon women (JohnstonRobledo et al. 2003; Roberts et al. 2002; Roberts and Waters 2004). Women also experience pressures to remove their body hair and pubic hair as indicators of femininity, heterosexuality, and respectability (Basow and Braman 1998; Fahs 2011b; Fahs and Delgado 2011). Embodiment during pregnancy, childbirth, and breastfeeding has also appeared in the literature in recent years, as women face enormous contradictions and conflicts about their pregnant bodies (Gatrell 2007; Nash 2012; Oliver 2010).

Further, pressures for women to remain thin and men to be muscular and fit are common and both work to discipline and control their bodies (Lanzieri and Hildebrandt 2011; Morrison et al. 2003). Women often use exercise as a means to regulate their bodies, trim down and feel socially acceptable while men often exercise to bulk up and show their physical prowess (Craig and Liberti 2007; Furnham et al. 2002; Strelan et al. 2003). Moreover women are much more likely to turn to invasive surgeries to look young and thin, as one study noted that $48 \%$ of women and $23 \%$ of men were interested in having cosmetic surgery (Frederick et al. 2007). Notably, far more research has interrogated gay male embodiment (Grogan et al. 2006; Monaghan 2005; Morrison et al. 2004) in comparison to heterosexual men's embodiment (Frith and Gleeson 2004; Marshall and Katz 2002). A few studies have examined men's relationship with their sperm (Moore 2011), but most studies of men's sexual embodiment have focused on "top" and "bottom" identities, experiences of anal penetration, and how those identities and experiences relate to sexual desire, satisfaction, and power (Hoppe 2011; Kippax and Smith 2001; Middelthon 2002).

\subsubsection{Old Age}

Studies of older adults and their experiences with embodiment are also quite limited. There are few studies on body image among the elderly (Feingold and Mazzella 1998) though one study found that men's self-rated attractiveness actually increased as they aged throughout adulthood (Slevin and Mowery 2012). Other studies have found that aging was not beneficial to women's impressions of their bodies, as women's body image remained the same throughout their senior years (Lewis and Cachelin 2001). Habitual body monitoring and appearance anxiety decreased as women passed middle-age (Tiggemann 2004), but many female senior citizens are still concerned about looking younger, having firmer breasts, and staying thin (Slevin 2010). Some research has examined women's experiences with menopause as a transitional phase of life, finding that women felt most distressed about the loss of bodily control, the possibility of having their motherly roles diminish in importance, and the violation of "normative" femininity that came with menopause (Dillaway 2011). Social identities also connected to women's experiences of menopause, as working class women experienced more intense menopausal symptoms than middle and upper class women (Martin 2001). Further, middle class white women reported more positive feelings about their bodies during menopause compared to women of color and working class women, citing that they no longer needed to worry about contraception and could enjoy sex more as a result (Dillaway 2005; Loe 2004).

Concerns about sexuality also shift and change during old age, as people face personal transitions. For men, pressures to take Viagra and maintain erectile functioning exist as ways to prove their masculinity (Lodge and Umberson 2012) (with new markets supporting these efforts, see Katz and Marshall 2003), while women faced frustration about the lack of male partners and men's loss of sexual functioning (Loe 2004). 
Conflicts about feeling disgust toward sexualizing older bodies also appeared (Vares 2009), with clear ideas about who gets to have a "sexual body" clearly internalized in old age. Along these lines, Black women's sexuality remained almost completely invisible in the literature on aging and sexuality (Dickerson and Rousseau 2009), suggesting notable gaps in the existing research on aging and sexuality.

\subsection{Part 4: Sexual Performance and Embodiment}

\subsubsection{Producing Body Parts}

Sexual performances also relate deeply to people's ideas about embodiment, particularly as related to worries and concerns about specific parts and regions of their own bodies. Women's breasts are often targeted as sites of anxious embodiment, with women worrying about their breast sizes and shapes in relation to their body images (Millsted and Frith 2003). Cultural prescriptions of attractive breasts relate deeply to patriarchal constructions of "good bodies," leading some women to pursue cosmetic surgery to enlarge their breasts (Young 2005a).

For men, the penis has represented a source of anxious embodiment, as men worried about whether their penises were too small and would disappoint their partners (Del Rosso 2011; Nugteren et al. 2010; Tiggemann et al. 2008). Moreover, racist stereotypes are connected to white men's fears of smaller penises (Wong et al. 2013). Viagra and the push toward the "always hard" penis has also influenced standards for masculinity as perpetually phallic, even into old age (Loe 2004; Maddison 2009). Men who had a tendency to think that their penises were smaller than other men also reported higher levels of self-doubt and shame (Tiggemann et al. 2008).

Further, anxieties around hair-hair on the head, underarm hair, leg hair, and pubic hairhave also appeared in the decades following the sexual revolution, as women feel compelled to remain completely hairless in their pubic, leg, and underarm regions (Fahs 2011b, 2012, 2014). Ap- proximately $99 \%$ of women have reported that they had removed body hair at some point in their lives (Toerien et al. 2005). Women who refused to remove their body hair faced external appraisals of themselves as disgusting, manly, unattractive, and gross (Fahs 2011b). While some men "manscape" or trim their pubic hair (Boroughs et al. 2005), most men feel entitled to choose the degree to which they will remain hairy, while women do not feel entitled to similar levels of choice around their body hair (Braun et al. in press). Conversely, men of all ages reported worries that their masculinity would be ridiculed by other men if their hair styles were too feminine or if they started balding on their heads (Ricciardelli 2011). Women of color in particular faced more severe penalties than white women for choosing to have body hair, particularly when family members expressed concerns with "respectability" (Fahs and Delgado 2011). With regard to pubic hair, younger and partnered women reported that they were more likely to remove pubic hair than older and non-partnered women (Herbenick et al. 2010b), suggesting social and contextual factors in which women remove pubic hair.

Social scientists have also identified women's genital self-image, or how women feel about their vulvas and pubic hair, as relevant to their body images more broadly (Roberts and Waters 2004; Schick et al. 2010). Because women receive messages that their bodies are always failing and inadequate, and that they are not desirable in their natural states, women have internalized the need for cleaning, sanitizing, deodorizing, exfoliating, and even surgically altering their bodies and their genitals (Bartky 1990). Many women, for example, expressed frank disgust at the idea of having menstrual sex (Fahs 2011c) or allowing a partner to perform oral sex on them (Bay-Cheng and Fava 2011). Conversely, more positive genital self-image correlated with greater likelihood of health-seeking behaviors like gynecological exams (DeMaria et al. 2011; Herbenick and Reece 2010). Women with positive genital selfimage also reported more frequent vibrator use, masturbation, genital self-examinations, and gynecological appointments (Herbenick et al. 2010a). 
In response to pressures to have conforming vulvas and vaginas, women have also faced new pressures to alter their genitals in order to obtain a more standardized (and perhaps "pornified") look. This "disease mongering" has led to pressures for women to engage in labiaplasties, vaginal "rejuvenation," the injection of Botox into women's G-spots, and the tightening of the vagina (Braun 2005; Braun and Tiefer 2010). Women who underwent labiaplasties did not report improvements in their sex lives (Bramwell et al. 2007).

\subsubsection{Orgasm}

Sexual satisfaction and orgasm also constitute a sizeable portion of the literature on sexual embodiment. Deciding how to measure satisfaction, and how much orgasm factors into such measurements, has preoccupied sex researchers for some time (McClelland 2010). Though sexual frequency and sexual satisfaction were sometimes synonymous (Waite and Joyner 2001), the research on sexual compliance suggests that a large number of women have boring or unpleasurable sex to please their male partners (Katz and Tirone 2009; Vannier and O'Sullivan 2010). One study found that sexual satisfaction and sexual activity were often misaligned, as younger women, women of color, less educated women, and lower socioeconomic status women reported having lower sexual satisfaction and higher sexual activity (Fahs and Swank 2011).

Research on orgasm has revealed much about the relationship between gender, power, and embodiment (Braun et al. 2003). Heterosexual women fake orgasm three times more often than heterosexual men (Muehlenhard and Shippee 2010). Women also often fake orgasms in an other-directed fashion, they want to please their male partners, end the encounter, feel sexually normal, avoid negative reactions, and reinforce a (male) partner's sexual skills (Fahs 2011a; Frith 2013). Conversely, men are more likely to fake orgasm for their own benefit and motivations such as wanting to sleep or feeling too intoxicated to gain an erection (Muehlenhard and Shippee
2010). Orgasm also represents the material, and perhaps capitalistic, impulses toward production of outcomes during sex, and toward embodiment as a concrete entity (Jackson and Scott 2007). Some humanists have also taken up orgasm as a subject of interest, as performance artist Frueh (2003) explored orgasm in relation to artistic expression, while Jagose (2010) characterized the fake orgasm as indicative of the failures of heterosexual sex.

\subsubsection{Trans Embodiment}

In recent years, more attention has been paid to trans embodiment and the ways that trans bodies can disrupt previously held notions of clear gendered dichotomies (Feinberg 1996; see also Devor and Dominic, this volume). Trans bodies, particularly those in the process of transitioning, are often seen as liminal, "on the edge," in the middle, or completely out of sight, both on television and in material, lived realities (Booth 2011), raising new possibilities for an examination of queer identities and their important, disruptive impact on assumptions about heterosexuality (Nash 2010). Trans people have also fought to have their (often forgotten or obscured) histories recognized and to fight against dichotomies of gender that often ignore the experiences of "third gender" and "middle gender" bodies (Halberstam 2005).

Trans bodies have been terrorized, pathologized, and confined in many different institutional spaces, including the mental health system, which often fails to provide adequate care for trans individuals (Israel et al. 2008; Mohr et al. 2001), and pathologizes transgender identity as "Gender Identity Disorder" (Lombardi et al. 2002; Winter et al. 2009). Prisons are also often places where trans people are discarded, neglected, and much misunderstood (Smith and Stanley 2011). Conflicts between the trans community and the gay, lesbian, and bisexual community have also appeared prominently in recent years (Feinberg 1996; Stone 2009), as whether drag are either celebrities or people to be mocked (Taylor and Rupp 2004) or whether transwomen 
can enter "women-only" feminist spaces (Goldberg 2014). Ultimately, the emerging debates and theories around trans identities and trans embodiment have provided fruitful new directions for the field of embodiment studies more broadly (Stryker and Whittle 2006).

\subsection{Part 5: Embodied Resistance}

\subsubsection{Who Fights Back and How?}

While much of the literature on embodiment has discussed people's compliance with social norms and their desire to conform to socially-acceptable modes of embodiment, there is also a growing, sizeable literature on embodied resistance (Bobel and Kwan 2011; Gagné and Tewksbury 1998). Resistance of this sort uses the body to convey a message that "inverts, contradicts, abrogates" (Pitts 1999, p. 71) culturally prescribed codes. Whether through reframing deviant bodies as healthy, normal, or "cool," or through fighting back against certain social regulations, the body as a site of resistance is ever evolving and changing. For example, fighting back through embracing tattoo art (Atkinson 2002), embracing fatness (Johnston and Taylor 2008; Meleo-Erwin 2012), or engaging in gender-bending modes of physical activity like women's roller derby (Peluso 2011), belly dancing (Moe 2011), or performing as a drag queen (Taylor and Rupp 2004), the body as a site of political, social, and cultural resistance has become an increasingly relevant facet of modern life.

The body has also figured centrally in political activism, as less powerful people use their bodies to engage in hidden or covert resistance. For example, working slowly, feigning sickness, monkey wrenching, or stealing from workplaces all constitute modes of hidden resistance (Scott 1990). During social movements and collective political campaigns, social movements routinely get people to use their bodies to protest at lowrisk marches and picket lines (Roscigno and Hodson 2004; Schussman and Soule 2005) or during high-risk periods where public displays of civil resistance are needed (Nepstead 2005;
Swank and Fahs 2013). Religious activists have burned themselves to stop wars (Ben Park 2004), while antiracists have used their bodies to protest Klan marches (Jipson and Becker 2001), and environmentalists have stopped traffic on freeways (St. John 2008). Abortion clinic escorts and pro-choice advocates have also used their bodies to fight back against the forces that seek to strip women's right to abortion away from them (DilOrio and Nusbaumer 1993). While some people consider these potentially dangerous uses of the body as counterproductive, several studies have found that disruptive tactics of this sort can produce positive social change under the right conditions (Cress and Snow 2000; Haines 1984; King 2011).

New social movements like feminism and environmentalism are especially interested in changing social norms and using the body as a key site of resistance. For example, menstrual activists have fought back against the commercial menstrual product industry by citing the dangers of tampons and dioxins (Bobel 2006), arguing against the inclusion of "Premenstrual Dysphoric Disorder" in the DSM (Offrnan and Kleinplatz 2004), and have worked to lessen the shaming and secrecy of menstruation in the culture at large (Bobel 2006). Both within and outside of universities, feminists have fought back against constructions of their bodies as "disgusting" and "failing" (Fahs 2013).

People have also sought to publicly resist "slut shaming" and the treatment of women's sexual selves as inherently shameful and "sinful." The notion that women deserve to be raped, or should be punished for having active sexualities, has been strongly refuted by feminists and sexpositive advocates (Martin 2005; White 1999). Slutwalks (seeking to end the "blame the victim" mentality around rape and to end rape culture) have emerged as one way people have resisted the shaming of women's sexualities (Carr 2013), while plays like The Vagina Monologues have also allowed for more public discourse about women's vaginas and vulvas (particularly on college campuses where the play is performed nearly every Valentine's Day) (Ensler 2007). Work to reclaim women's bodies and sexualities as po- 
litical entities, often within a feminist lens, have constituted much of the recent work on embodied resistance and liberation.

\subsubsection{Bodies Outside of the Norm}

Embodied resistance work has also focused on valuing bodies often deemed as "Other" or different from the mainstream. Some of this work includes advocacy for the sexuality of disabled people (Shildrick 2007), fighting for more visibility for women of color (Lee 2000), reclaiming fatness as a space of social resistance (Joanisse and Synnott 1999), and advocacy for "pro-ana" websites that promote solidarity among anorexic people (Dias 2013). Other examples of such work include alternative pornography films (Attwood 2007), more radical conceptualizations of mental health and how to promote bodily wellness (Hendricks and Plummer 2013), and body modification practices (Pitts 2003). Collectively, this work often openly fights not only for the right for Othered bodies to exist, but instead frames these Othered bodies as important tools of resistance.

\subsection{3 "Freak" Studies}

As an outgrowth of disability studies, postcolonial/subaltern studies, and fat studies, "freak studies" (Chemers 2005) is now an emerging field that encompasses a radical reinvisioning of Othered bodies as themselves worthy of both study and critical interrogation. For example, freak studies takes up not only the literal treatment of the freak in popular culture (Adams 2001), but also the larger issues around bodies that refuse to conform (Stryker 1994). Courses in freak studies and the examination of "freak" bodies have started to appear across the country, often fusing together work that is clearly antiassimilationist (that is, against the idea that bodies should conform to the mainstream) and radically diverse (Sherry 2004). The field also works to closely interrogate the intersections between trans bodies, disabled bodies, fat bodies, bodies of color, queer bodies, and other bodies out of bounds (Chemers 2005).

\subsubsection{Anarchism and the Sexual Body}

Embodiment has also been conceptualized recently within the anarchist literatures, particularly as scholars have started to interrogate the radical potential in envisioning sexuality and love relationships as distinctly political (Heckert and Cleminson 2011). Typically, anarchists have conceptualized sexuality as a mode of resistance against traditional or mainstream scripts of heterosexuality, marriage, coupling, and monogamy (Alexander 2011). More recently, incorporating ideas of asexuality and celibacy as acts of resistance (Fahs 2010) or seeing sexuality and love as fundamentally important to the project of political upheavals and revolution (Heckert and Cleminson 2011) have constituted new lines of thinking about how anarchy, sexuality, and embodiment can fuse together. Using the body as a tool of political protest can unite with the project of seeing the body as sexual (or not) and as deeply connected to other humans (Heckert and Cleminson 2011).

\subsection{Conclusion}

Ultimately, the study of embodiment presents a complicated array of ideas, practices, realities, and resistances, all of which reveal not only the central importance of the body to individual well-being, but to the very fabric of modern social life. Because institutional and cultural biases praise and condemn specific bodies in specific contexts, embodiment as individual awareness of one's body can be empowering or disempowering, contradictory or straight forward, and it can elicit deep connections to social identities like race, class, sexuality, gender, size, disability, and nationality. Most importantly, the body is a fluid text upon which many contemporary issues are written and rewritten. It can be a regressive, conservative force, framing people within insidi- 
ous stereotypes and embodied practices, or it can serve as a site of resistance and upheaval, making new ideas and new worlds within which people's bodies can move and exist. As such, embodiment has paramount importance in the study not only of the sexual self, but of the human experience more broadly.

\section{References}

Adams, R. (2001). Sideshow U.S.A.: Freaks and the American cultural imagination. Chicago: University of Chicago Press.

Albanesi, H. P. (2009). Gender and sexual agency: How young people make choices about sex. Lanham: Lexington Books.

Alcoff, L. M. (2005). Visible identities: Race, gender, and the self. New York: Oxford University Press.

Alexander, J. (2011). Alexander Berkman: Sexual dissidence in the first wave anarchist movement and its subsequent narratives. In J. Heckert \& R. Cleminson (Eds.), Anarchism \& sexuality: Ethics, relationships, and power (pp. 25-44). London: Palgrave.

Atkinson, M. (2002). Pretty in ink: Conformity, resistance, and negotiation in women's tattooing. Sex Roles, 47(5-6), 219-235.

Attwood, F. (2007). No money shot? Commerce, pornography, and new sex taste cultures. Sexualities, 10(4), 441-456.

Bancroft, J. (2003). Sexual development in childhood. Bloomington: Indiana University Press.

Bartky, S. L. (1990). Femininity and domination: Studies in the phenomenology of oppression. Florence: Psychology Press.

Basow, S. A., \& Braman, A. C. (1998). Women and body hair: Social perceptions and attitudes. Psychology of Women Quarterly, 22(4), 637-645.

Bates, C. (2013). Video diaries: Audio-visual research methods and the elusive body. Visual Studies, 28(1), 29-37.

Bay-Cheng, L. Y., \& Fava, N. M. (2011). Young women's experiences and perceptions of cunnilingus during adolescence. Journal of Sex Research, 48(6), 531-542.

Ben Park, B. C. (2004). Sociopolitical contexts of selfimmolations in Vietnam and South Korea. Archives of Suicide Research, 8(1), 81-97.

Bessenoff, G. R., \& Snow, D. (2006). Absorbing society's influence: Body image self-discrepancy and internalized shame. Sex Roles, 54(9-10), 727-731.

Bobel, C. (2006). "Our revolution has style:” Contemporary menstrual product activists "doing feminism" in the third wave. Sex Roles, 54(5-6), 331-345.

Bobel, C., \& Kwan, S. (2011). Embodied resistance: Challenging the norms, breaking the rules. Nashville: Vanderbilt University Press.
Booth, E. T. (2011). Queering queer eye: The stability of gay identity confronts the liminality of trans embodiment. Western Journal of Communication, 75(2), 185-204.

Bordo, S. (1993). Feminism, Foucault, and the politics of the body. In C. Ramazanoglu (Ed.), Up against Foucault: Explorations of some tensions between Foucault and feminism (pp. 179-202). Florence: Psychology Press.

Boroughs, M., Cafri, G., \& Thompson, J. K. (2005). Male body depilation: Prevalence and associated features of body hair removal. Sex Roles, 52(9-10), 637-644.

Bourdieu, P. (1977). Outline of a theory of practice. Cambridge: Cambridge University Press.

Boyd, E. M., Reynolds, J. R., Tillman, K. H., \& Martin, P. Y. (2011). Adolescent girls' race/ethnic status, identities, and drive for thinness. Social Science Research, 40(2), 667-684.

Braidotti, R. (1994). Nomadic subjects: Embodiment and sexual difference in contemporary feminist theory. New York: Columbia University Press.

Bramwell, R., Morland, C., \& Garden, A. S. (2007). Expectations and experience of labial reduction: A qualitative study. BJOG: An International. Journal of Obstetrics and Gynecology, 114(2), 1493-1499.

Braun, V. (2005). In search of (better) sexual pleasure: Female genital "cosmetic" surgery. Sexualities, 8(4), 407-424.

Braun, V., \& Clarke, V. (2006). Using thematic analysis in psychology. Qualitative Research in Psychology, 3(2), 77-101.

Braun, V., \& Tiefer, L. (2010). The "designer vagina" and the pathologisation of female genital diversity: Interventions for change. Radical Psychology, 8(1).

Braun, V., Gavey, N., \& McPhillips, K. (2003). The fair deal? Unpacking accounts of reciprocity in heterosex. Sexualities, 6(2), 237-261.

Braun, V., Tricklebank, G., \& Clarke, V. (in press). "It shouldn't stick out from your bikini at the beach:" Meaning, gender, and the hairy/hairless body. Psychology of Women Quarterly.

Brown, S. D., Cromby, J., Harper, D. J., Johnson, K., \& Reavey, P. (2011). Researching "experience:" Embodiment, methodology, process. Theory \& Psychology, 21(4), 493-515.

Butler, J. (1990). Gender trouble. New York: Routledge.

Cahill, A. J. (2011). Overcoming objectification: A carnal ethics. New York: Routledge.

Carr, J. L. (2013). The SlutWalk movement: A study in transnational feminist activism. Journal of Feminist Scholarship, 4, 24-38.

Chemers, M. M. (2005). Introduction: Staging stigma: A freak studies manifesto. Disability Studies Quarterly, 25(3).

Chrisler, J. C. (2012). "Why can't you control yourself?" Fat should be a feminist issue. Sex Roles, 66(9-10), 608-616.

Collins, P. H. (1999). Black feminist thought: Knowledge, consciousness, and the politics of empowerment. New York: Routledge. 
Connell, R. W. (2005). Masculinities. Berkeley: University of California Press.

Coy, M., \& Garner, M. (2012). Definitions, discourses, and dilemmas: Policy and academic engagement with the sexualisation of popular culture. Gender and Education, 24(3), 285-301.

Craig, M. L., \& Liberti, R. (2007). "Cause that's what girls do:" The making of a feminized gym. Gender \& Society, 21(5), 676-699.

Cress, D. M., \& Snow, D. A. (2000). The outcomes of homeless mobilization: The influence of organization, disruption, political mediation, and framing. The American Journal of Sociology, 105(4), 1063-1104.

Crossley, N. (1996). Body-subject/body-power: Agency, inscription and control in Foucault and MerleauPonty. Body and Society, 2(2), 99-116.

Curtis, D. (2009). Pleasure and perils: Girls'sexuality in a Caribbean consumer culture. New Jersey: Rutgers University Press.

Del Rosso, J. (2011). The penis as public art: Embodiment and the performance of masculinity in public settings. Sexualities, 14(6), 704-724.

DeLamater, J. D., \& Hyde, J. S. (1998). Essentialism vs. social constructionism in the study of human sexuality. Journal of Sex Research, 35(1), 10-18.

DeMaria, A. L., Hollub, A. V., \& Herbenick, D. (2011). Using genital self-image, body image, and sexual behaviors to predict gynecological exam behaviors of college women. Journal of Sexual Medicine, 8(9), 2484-2492.

Diamond, L. (2008). Sexual fluidity: Understanding women's love and desire. Cambridge: Harvard University Press.

Dias, K. (2013). The ana sanctuary: Women's proanorexia narratives in cyberspace. Journal of International Women's Studies, 4(2), 31-45.

Dickerson, B. J., \& Rousseau, N. (2009). Ageism through omission: The obsolescence of black women's sexuality. Journal of African American Studies, 13(3), 307-324.

Dillaway, H. E. (2005). Menopause is the "good old:" Women's thoughts about reproductive aging. Gender and Society, 19(3), 398-417.

Dillaway, H. E. (2011). Menopausal and misbehaving: When women "flash" in front of others. In C. Bobel \& S. Kwan (Eds.), Embodied resistance: Challenging the norms, breaking the rules (pp. 197-208). Nashville: Vanderbilt University Press.

DilOrio, J. A., \& Nusbaumer, M. R. (1993). Securing our sanity: Anger management among abortion escorts. Journal of Contemporary Ethnography, 21(4), 411-438.

Earle, S. (2003). "Bumps and boobs:" Fatness and women's experiences of pregnancy. Women's Studies International Forum, 26(3), 245-252.

Ensler, E. (2007). The vagina monologues. New York: Villard Books.

Eriksen, S., \& Goering, S. (2011). A test of the agency hypothesis in women's cosmetic surgery usage. Sex Roles, 64(11-12), 888-901.
Fahs, B. (2009). Compulsory bisexuality? The challenges of modern sexual fluidity. Journal of Bisexuality, 9(3), 431-449.

Fahs, B. (2010). Radical refusals: On the anarchist politics of women choosing asexuality. Sexualities, 13(4), 445-461.

Fahs, B. (2011a). Performing sex: The making and unmaking of women's erotic lives. Albany: SUNY Press.

Fahs, B. (2011b). Dreaded “Otherness:" Heteronormative patrolling in women's body hair rebellions. Gender \& Society, 24(4), 451-472.

Fahs, B. (2011c). Sex during menstruation: Race, sexual identity, and women's qualitative accounts of pleasure and disgust. Feminism \& Psychology, 21(2), 155-178.

Fahs, B. (2012). Breaking body hair boundaries: Classroom exercises for challenging social constructions of the body and sexuality. Feminism \& Psychology, 22(4), 482-506.

Fahs, B. (2013). Raising bloody hell: Inciting menstrual panics through campus and community activism. In B. Fahs, M. L. Dudy, \& S. Stage (Eds.), The moral panics of sexuality (pp. 77-91). London: Palgrave.

Fahs, B. (2014). Perilous patches and pitstaches: Imagined versus lived experiences of women's body hair growth. Psychology of Women Quarterly, 38(2), 167-180.

Fahs, B., \& Delgado, D. (2011). The specter of excess: Race, class, and gender in women's body hair narratives. In C. Bobel \& S. Kwan (Eds.), Embodied resistance: Challenging the norms, breaking the rules (pp. 13-25). Nashville: Vanderbilt University Press.

Fahs, B., \& Swank, E. (2011). Social identities as predictors of women's sexual satisfaction and sexual activity. Archives of Sexual Behavior, 40(5), 903-914.

Fahs, B., Dudy, M. L., \& Stage, S. (2013). The moral panics of sexuality. London: Palgrave.

Feinberg, L. (1996). Transgender warriors: Making history from Joan of Arc to Dennis Rodman. Boston: Beacon Press.

Feingold, A., \& Mazzella, R. (1998). Gender differences in body image are increasing. Psychological Science, 9, 190-195.

Fine, M. (1988). Sexuality, schooling, and adolescent females: The missing discourse of desire. Harvard Educational Review, 58(1), 29-54.

Fine, M., \& McClelland, S. I. (2006). Sexuality education and desire: Still missing after all these years. Harvard Educational Review, 76(3), 297-338.

Foroni, F., \& Semin, G. R. (2012). Not all implicit measures of attitudes are created equal: Evidence from an embodied perspective. Journal of Experimental Social Psychology, 48(1), 424-427.

Foster, J., \& Strack, F. (1996). Influence of overt head movements on memory for valenced words: A case of conceptual motor compatibility. Journal of Personality and Social Psychology, 71, 421-430.

Foucault, M. (1977). Discipline and punish: The birth of the prison. New York: Vintage.

Foucault, M. (1978). The history of sexuality (Vol. 1). New York: Random House. 
Foucault, M. (1984). The Foucault reader. New York: Random House.

Frederick, D. A., Lever, J., \& Peplau, L. A. (2007). Interest in cosmetic surgery and body image: Views of men and women across the lifespan. Plastic and Reconstructive Surgery, 120(5), 1407-1415.

Friedrich, W. (2003). Studies of sexuality of nonabused children. In J. Bancroft (Ed.), Sexual development in childhood (pp. 107-120). Bloomington: Indiana University Press.

Frith, H. (2013). Labouring on orgasms: Embodiment, efficiency, entitlement, and obligations in heterosex. Culture, Health \& Sexuality, 15(4), 494-510.

Frith, H., \& Gleeson, K. (2004). Clothing and embodiment: Men managing body image and appearance. Psychology of Men \& Masculinity, 5(1), 40-48.

Frueh, J. (2003). The aesthetics of orgasm. Sexualities, 6(3-4), 459-478.

Furnham, A., Badmin, N., \& Sneade, I. (2002). Body image dissatisfaction: Gender differences in eating attitudes, self-esteem, and reasons for exercise. Journal of Psychology, 136(6), 581-596.

Gagné, P., \& Tewksbury, R. (1998). Conformity pressures and gender resistance among transgendered individuals. Social Problems, 45, 81-101.

Gatens, M. (1996). Imaginary bodies: Ethics, power, and corporeality. New York: Routledge.

Gatrell, C. J. (2007). Secrets and lies: Breastfeeding and professional paid work. Social Science \& Medicine, 65(2), 393-404.

Gillies, V., Harden, A., Johnson, K., Reavey, P., Strange, V., \& Willig, C. (2004). Women's collective constructions of embodied practices through memory work: Cartesian dualism in memories of sweating and pain. British Journal of Social Psychology, 43(1), 99-112.

Gleeson, K., \& Frith, H. (2004). Pretty in pink: Young women presenting mature sexual identities. In A. Harris (Ed.), All about the Girl: Culture, power and identity (pp. 103-114). New York: Routledge.

Glenberg, A. M. (2010). Embodiment as a unifying perspective for psychology. Cognitive Science, 1(4), 586-596.

Goldberg, M. (2014).Whatisawoman?Thedisputebetween radical feminism and transgenderism. New Yorker. http://www.newyorker.com/magazine/2014/08/04/ woman-2. Accessed 9 Aug 2014.

Graham, C. (2003). Methodological issues involved in adult recall of childhood sexual experiences. In J. Bancroft (Ed.), Sexual development in childhood (pp. 67-76). Bloomington: Indiana University Press.

Grogan, S., Conner, M., \& Smithson, H. (2006). Sexuality and exercise motivations: Are gay men and heterosexual women most likely to be motivated by concern about weight and appearance? Sex Roles, 55(7), 567-572.

Grollman, E. A. (2012). Multiple forms of perceived discrimination and health among adolescents and young adults. Journal of Health and Social Behavior, 53(2), 199-214.
Grosz, E. (1994). Volatile bodies: Toward a corporeal feminism. Bloomington: Indiana University Press.

Grosz, E. (2008). Chaos, territory, art: Deleuze and the framing of the earth. New York: Columbia University Press.

Haines, H. H. (1984). Black radicalization and the funding of civil rights, 1957-1970. Social Problems, 32(1), $31-43$.

Halberstam, J. (1998). Female masculinity. Durham: Duke University Press.

Halberstam, J. (2005). In a queer time and place: Transgender bodies, subcultural lives. New York: New York University Press.

Hannabach, C. (2007). Anxious embodiment, disability, and sexuality: A response to Margrid Shildrick. Studies in Gender and Sexuality, 8(3), 253-261.

Haraway, D. (1991). Simians, cyborgs, and women. New York: Routledge.

Hassouneh-Phillips, D., \& McNeff, E. (2005). "I thought I was less worthy": Low sexual and body esteem and increased vulnerability to intimate partner abuse in women with physical disabilities. Sexuality and Disability, 23(4), 227-240.

Hauge, M. (2009). Bodily practices and discourses of hetero-femininity: Girls' constitution of subjectivities in their social transition between childhood and adolescence. Gender and Education, 21(3), 293-307.

Heckert, J., \& Cleminson, R. (2011). Anarchism \& sexuality: Ethics, relationships, and power. London: Routledge.

Hendricks, K., \& Plummer, S. (2013). Re-thinking wellness: A feminist approach to health and fitness. Gender Forum, 45.

Hepburn, A. (2006). Getting closer at a distance: Theory and the contingencies of practice. Theory \& Psychology, 16(3), 327-342.

Herbenick, D., \& Reese, M. (2010). Development and validation of the female genital self-image scale. Journal of Sexual Medicine, 7(5), 1822-1830.

Herbenick, D., Schick, V., Reece, M., Sanders, S., Dodge, B., \& Fortenberry, D. (2010a). The female genital selfimage scale (FGSIS): Results from a nationally representative probability sample of women in the United States. Journal of Sexual Medicine, 8(1), 158-166.

Herbenick, D., Schick, V., Reece, M., Sanders, S., \& Fortenberry, D. (2010b). Pubic hair removal among women in the United States: Prevalence, methods, and characteristics. Journal of Sexual Medicine, 7(10), 3322-3330.

Herdt, G., \& McClintock, M. (2000). The magical age of 10. Archives of Sexual Behavior, 29(6), 587-606.

Heyes, C. J. (2007). Cosmetic surgery and the televisual makeover: A Foucauldian feminist reading. Feminist Media Studies, 7(1), 17-32.

Hillyer, B. (1998). The embodiment of old women: Silences. Frontiers, 19(1), 48-60.

Hill Collins, P. (1990). Black feminist thought: Knowledge, consciousness, and the politics of empowerment. New York: Routledge. 
Holland, J., \& Thomson, R. (2010). Revisiting youthful sexuality: Continuities and changes over two decades. Sexual and Relationship Therapy, 25(3), 342-350.

Holland, J., Ramazanoglu, C., \& Sharpe, S. (1994). Power and desire: The embodiment of female sexuality. Feminist Review, 46, 21-38.

Hoppe, T. (2011). Circuits of power, circuits of pleasure: Sexual scripting in gay men's bottom narratives. Sexualities, 14(2), 193-217.

Hunter, M. L. (2002). "If you're light you're alright:" Light skin as social capital for women of color. Gender \& Society, 16(2), 175-193.

Hyde, J. (2003). The use of meta-analysis in understanding the effects of child sexual abuse. In J. Bancroft (Ed.), Sexual development in childhood (pp. 82-91). Bloomington: Indiana University Press.

Impett, E. A., Henson, J. M., Breines, J. G., Schooler, D., \& Tolman, D. L. (2011). Embodiment feels better: Girls body objectification and well being across adolescence. Psychology of Women Quarterly, 35(1), 46-58.

Inckle, K. (2014). A lame argument: Profoundly disabled embodiment as critical gender politics. Disability \& Society, 29(3), 388-401.

Irigaray, L. (1985). This sex which is not one. Ithaca: Cornell University Press.

Israel, T., Gorcheva, R., Burnes, T. R., \& Walther, W. A. (2008). Helpful and unhelpful therapy experiences of LGBT clients. Psychotherapy Research, 18(3), 294-305.

Jackson, S., \& Scott, S. (2007). Faking it like a woman? Towards an interpretive theorization of sexual pleasure. Body and Society, 13(2), 95-116.

Jagose, A. (2010). Counterfeit pleasures: Fake orgasm and queer agency. Textual Practice, 24(3), 517-539.

Jipson, A., \& Becker, P. (2001). Protesting Klan rallies: What can we learn from community organizations vs. non-local countermovements? Research in Political Sociology, 9, 233-268.

Joanisse, L., \& Synnott, A. (1999). Fighting back: Reactions and resistance to the stigma of obesity. In J. Sobal \& D. Maurer (Eds.), Interpreting weight: The social management of fatness and thinness (pp. 49-60). Piscataway: Transaction Publishers.

Johnson-Robledo, I., Ball, M., Lauta, K., \& Zekoll, A. (2003). To bleed or not to bleed: Young women's attitudes toward menstrual suppression. Women \& Health, 38(3), 59-75.

Johnston, J., \& Taylor, J. (2008). Feminist consumerism and fat activists: A comparative study of grassroots activism and the Dove real beauty campaign. Signs, 33(4), 941-966.

Jones, D. C. (2001). Social comparison and body image: Attractiveness comparisons to models and peers among adolescent girls and boys. Sex Roles, 45(9-10), 645-664.

Katz, S., \& Marshall, B. (2003). New sex for old: Lifestyle, consumerism, and the ethics of aging well. Journal of Aging Studies, 17(1), 3-16.
Katz, J., \& Tirone, V. (2009). Women's sexual compliance with male dating partners: Associations with investment in ideal womanhood and romantic well-being. Sex Roles, 60(5-6), 347-356.

Kimmel, M. S. (2004). Masculinity as homophobia: Fear, shame, and silence in the construction of gender identity. In P. D. Rothenberg (Ed.), Race, class, and gender in the United States: An integrated study (pp. 81-93). New York: Worth.

King, B. G. (2011). The tactical disruptiveness of social movements: Sources of market and mediated disruption in corporate boycotts. Social Problems, 58(4), 491-517.

Kippax, S., \& Smith, G. (2001). Anal intercourse and power in sex between men. Sexualities, 4(4), 413-434.

Lamb, S., \& Coakley, M. (1993). 'Normal' childhood sexual play and games: Differentiating play from abuse. Child Abuse and Neglect, 17(4), 515-526.

Lanzieri, N., \& Hildebrandt, T. (2011). Using hegemonic masculinity to explain gay male attraction to muscular and athletic men. Journal of Homosexuality, 58(2), 275-293.

Laqueur, T. (2003). Solitary sex: A cultural history of masturbation. Cambridge: Zone Books.

Le Espiritu, Y. (2001). "We don't sleep around like white girls do:" Family, culture, and gender in Filipina American lives. Signs, 26(2), 415-440.

Lee, R. (2000). Notes from the (non) field: Teaching and theorizing women of color. Meridians, 1(1), 85-109.

Lewis, D. M., \& Cachelin, F. M. (2001). Body image, body dissatisfaction, and eating attitudes in midlife and elderly women. Eating Disorders, 9(1), 29-39.

Lloyd, E. (2009). The case of the female orgasm: Bias in the science of evolution. Cambridge: Harvard University Press.

Lodge, A. C., \& Umberson, D. (2012). All shook up: Sexuality of mid to later life married couples. Journal of Marriage and Family, 74(3), 428-443.

Loe, M. (2004). Sex and the senior woman: Pleasure and danger in the Viagra era. Sexualities, 7, 303-326.

Loewenson, P. R., Ireland, M., \& Resnick, M. D. (2004). Primary and secondary sexual abstinence in high school students. Journal of Adolescent Health, 34(3), 209-215.

Lombardi, E. L., Wilchins, R. A., Priesing, D., \& Malouf, D. (2002). Gender violence: Transgender experiences with violence and discrimination. Journal of Homosexuality, 42(1), 89-101.

Lottes, I. L. (2002). Sexual health policies in other industrialized countries: Are there lessons for the United States? Journal of Sex Research, 39(1), 79-83.

Maddison, S. (2009). "The second sexual revolution:" Big pharma, porn, and the biopolitical penis. Topia, $22,35-53$.

Marshall, B. L., \& Katz, S. (2002). Forever functional: Sexual fitness and the ageing male body. Body and Society, 8(4), 43-70.

Martin, E. (2001). The woman in the body: A cultural analysis of reproduction. Boston: Beacon Press. 
Martin, P. Y. (2005). Rape work: Victims, gender, and emotions in organization and community context. Florence: Psychology Press.

Martins, Y., Tiggemann, M., \& Churchett, L. (2008). Hair today, gone tomorrow: A comparison of body hair removal practices in gay and heterosexual men. Body Image, 5(3), 312-316.

Masters, W. H., \& Johnson, V. E. (1966). Human sexual response. Boston: Little, Brown, \& Co.

McClelland, S. I. (2010). Intimate justice: A critical analysis of sexual satisfaction. Social and Personality Psychology Compass, 4(9), 663-680.

McClelland, S. I. (2014). "What do you mean when you say that you're sexually satisfied?": A mixed methods study. Feminism \& Psychology, 24(1), 74-96.

McCreary, D. R., \& Sasse, D. K. (2000). An exploration of the drive for muscularity in adolescent boys and girls. Journal of American College Health, 48(6), 297-304.

Meleo-Erwin, Z. (2012). Disrupting normal: Toward the "ordinary and familiar" in fat politics. Feminism \& Psychology, 22(3), 388-402.

Merleau-Ponty, M. (1945). Phenomenology of perception. Paris: Gallimard.

Messerschmidt, J. W. (2000). Nine lives: Adolescent masculinities, the body, and violence. Boulder: Westview Press.

Meyer, I. H., Schwartz, S., \& Frost, D. M. (2008). Social patterning of stress and coping: Does disadvantaged social statuses confer more stress and fewer coping resources? Social Science \& Medicine, 67(3), 368-379.

Middlethon, A. (2002). Being anally penetrated: Erotic inhibitions, improvisations and transformations. Sexualities, 5(2), 181-200.

Millsted, R., \& Frith, H. (2003). Being large-breasted: Women negotiating embodiment. Women's Studies International Forum, 26(5), 455-465.

Minh-Ha, T. (1989). Woman, native, other. Bloomington: Indiana University Press.

Moe, A. M. (2011). Belly dancing mommas: Challenging cultural discourses of maternity. In C. Bobel \& S. Kwan (Eds.), Embodied resistance: Challenging the norms, breaking the rules (pp. 88-98). Nashville: Vanderbilt University Press.

Mohr, J., Israel, T., \& Sedlacek, W. (2001). Counselors' attitudes regarding bisexuality as predictors of counselors' clinical responses. Journal of Counseling Psychology, 48, 212-222.

Monaghan, L. F. (2005). Big handsome men, bears and others: Virtual constructions of "fat male embodiment." Body \& Society, 11(2), 81-111.

Moore, L. J. (2011). Sperm counts: Overcome by man's most precious fluid. New York: New York University Press.

Morgan, M. (2005). Hip-hop women shredding the veil: Race and class in popular feminist identity. South Atlantic Quarterly, 104(3), 425-444.

Morris, R. (2010). Can the subaltern speak? Reflections on the history of an idea. New York: Columbia University Press.
Morrison, T. G., Morrison, M. A., \& Hopkins, C. (2003). Striving for bodily perfection? An exploration of the drive for muscularity in Canadian men. Psychology of Men and Masculinity, 4, 111-120.

Morrison, M. A., Morrison, T. G., \& Sager, C. L. (2004). Does body satisfaction differ between gay men and lesbian women and heterosexual men and women? A meta-analytic review. Body Image, 1(2), 127-138.

Muehlenhard, C. L., \& Shippee, S. K. (2010). Men's and women's reports of pretending orgasm. Journal of Sex Research, 47(6), 552-567.

Nash, C. J. (2010). Trans geographies, embodiment, and experience. Gender, Place \& Culture, 17(5), 579-595.

Nash, M. (2012). Making "postmodern” mothers: Pregnant embodiment, baby bumps, and body image. London: Palgrave.

Nepstad, S. E. (2005). Disciplines and dissenters: Tactical choice and the consequences in the plowshares movement. Research in Social Movements, Conflicts, and Change, 25, 139-159.

Niedenthal, P. M., Brauer, M., Halberstadt, J. B., \& InnesKer, A. H. (2001). When did her smile drop? Facial mimicry and the influences of emotional state on the detection of change in emotional expression. Cognition and Emotion, 15, 853-864.

Noll, S. M., \& Frederickson, B. L. (1998). A mediational model linking self-objectification, body shame, and disordered eating. Psychology of Women Quarterly, 22(4), 623-636.

Nugteren, H. M., Balkema, G. T., Pascal, A. L., Schultz, W. C. M., Nijman, J. M., \& Van Driel, M. F. (2010). 18 -year experience in the management of men with a complaint of a small penis. Journal of Sex and Marital Therapy, 36(2), 109-117.

Offrnan, A., \& Kleinplatz, P. J. (2004). Does PMDD belong in the DSM? Challenging the medicalization of women's bodies. Canadian Journal of Human Sexuality, 13(1), 17-27.

Oliver, K. (2010). Motherhood, sexuality, and pregnant embodiment: Twenty-five years of gestation. Hypatia, 25(4), 760-777.

Pascoe, C. J. (2005). "Dude, you're a fag:” Adolescent masculinity and the fag discourse. Sexualities, 8(3), 329-346.

Peluso, N. M. (2011). “Cruisin' for the brusin:”' Women's flat track roller derby. In C. Bobel \& S. Kwan (Eds.), Embodied resistance: Challenging the norms, breaking the rules (pp. 37-47). Nashville: Vanderbilt University Press.

Pitts, V. (1999). Body modification, self-mutilation, and agency in media accounts of a subculture. Body \& Society, 5(2-3), 291-303.

Pitts, V. (2003). In the flesh: The cultural politics of body modification. London: Palgrave.

Plante, R. (2006). Sexualities in context: A social perspective. Boulder: Westview Press.

Probyn, E. (1993). Sexing the self: Gendered positions in cultural studies. Florence: Psychology Press.

Rademakers, J., Laan, M. J. C., \& Straver, C. J. (2003). Body awareness and physical intimacy: An explor- 
atory study. In J. Bancroft (Ed.), Sexual development in childhood (pp. 121-125). Bloomington: Indiana University Press.

Renold, E. (2005). Girls, boys and junior sexualities. New York: Routledge.

Renold, E. (2007). Primary school "studs:" (De)constructing young boys' heterosexual masculinities. Men \& Masculinities, 9, 275-297.

Renold, E., \& Ringrose, J. (2011). Schizoid subjectivities? Re-theorizing teen girls' sexual cultures in an era of "sexualization.". Journal of Sociology, 47(4), 389-409.

Ricciardelli, R. (2011). Masculinity, consumerism, and appearance: A look at men's hair. Canadian Review of Sociology, 48(2), 181-201.

Roberts, T., \& Waters, P. L. (2004). Self-objectification and that "not so fresh feeling:" Feminist therapeutic interventions for healthy female embodiment. Women and Therapy, 27(3-4), 5-21.

Roberts, T. A., Goldenberg, J. L., Power, C., \& Pyszczynski, T. (2002). "Feminine protection:" The effects of menstruation on attitudes toward women. Psychology of Women Quarterly, 26(2), 131-139.

Robinson, K. H. (2012). "Difficult citizenship:" The precarious relationships between childhood, sexuality, and access to knowledge. Sexualities, 15(3-4), 257-276.

Rohrer, T. (2007). The body in space: Dimensions of embodiment. In T. Ziemke, J. Zlatev, R. M. Frank, \& W. de Gruyter (Eds.), Embodiment (pp. 339-377). Berlin: Mouton de Gruyter.

Roscigno, V. J., \& Hodson, R. (2004). The organization and social foundations of worker resistance. American Sociological Review, 69(1), 14-39.

Rothblum, E., \& Solovay, S. (2009). The fat studies reader. New York: New York University Press.

Rubin, G. S. (1984). Thinking sex: Notes for a radical theory of the politics of sexuality. In H. Abelove, M. A. Barale, \& D. M. Halperin (Eds.), The lesbian and gay studies reader (pp. 3-44). New York: Routledge.

Ryan, G. (2000). Childhood sexuality: A decade of study. Part 1-Research and curriculum development. Child Abuse and Neglect, 24(1), 33-48.

Sanchez, D. T., \& Kiefer, A. K. (2007). Body concerns in and out of the bedroom: Implications for sexual pleasure and problems. Archives of Sexual Behavior, 36(6), 808.

Schalet, A. (2010). Sexual subjectivity revisited: The significance of relationships in Dutch and American girls' experiences of sexuality. Gender \& Society, 24(3), 304-329.

Schick, V. R., Calabrese, S. K., Rima, B. N., \& Zucker, A. N. (2010). Genital appearance dissatisfaction: Implications for women's genital image self-consciousness, sexual esteem, sexual satisfaction, and sexual risk. Psychology of Women Quarterly, 34(3), 394-404.

Schmied, V., \& Lupton, D. (2001). Blurring the boundaries: Breastfeeding and maternal subjectivity. Sociology of Health \& Illness, 23(2), 234-250.
Schussman, A., \& Soule, S. A. (2005). Process and protest: Accounting for individual protest participation. Social Forces, 84(2), 1083-1108.

Scott, J. C. (1990). Domination and the arts of resistance: Hidden transcripts. New Haven: Yale University Press.

Sedgwick, E. K. (1990). Epistemology of the closet. Berkeley: University of California Press.

Sherry, M. (2004). Overlaps and contradictions between queer theory and disability studies. Disability \& Society, 19(7), 769-783.

Shildrick, M. (2005). Unreformed bodies: Normative anxiety and the denial of pleasure. Women's Studies, 34(3-4), 327-344.

Shildrick, M. (2007). Contested pleasures: The sociopolitical economy of disability and sexuality. Sexuality Research \& Social Policy, 4(1), 53-66.

Shilling, C. (2004). The body in culture, technology, and society. New York: Sage.

Singh, S., Darroch, J. E., \& Frost, J. J. (2001). Socioeconomic disadvantage and adolescent women's sexual and reproductive behavior: The case of five developed countries. Family Planning Perspectives, 33(6), 251-289.

Slevin, K. F. (2010). "If I had lots of money...I'd have a body makeover:" Managing the aging body. Social Forces, 88(3), 1003-1020.

Slevin, K. F., \& Linneman, T. J. (2010). Old gay men's bodies and masculinities. Men and Masculinities, 12(4), 483-507.

Slevin, K. F., \& Mowery, C. (2012). Exploring embodied aging and ageism among old lesbians and gay men. In L. Carpenter \& J. DeLamater (Eds.), Sex for life, from virginity to Viagra: How sexuality changes throughout our lives (pp. 260-277). New York: New York University Press.

Smith, N., \& Stanley, E. A. (2011). Captive genders: Trans embodiment and the prison industrial complex. Oakland: AK Press.

Smith-Rosenberg, C. (1986). Disorderly conduct: Visions of gender in Victorian America. New York: Oxford University Press.

Spivak. G. (1999). A critique of postcolonial reason: Toward a history of the vanishing present. Cambridge: Harvard University Press.

St. John, G. (2008). Protestival: Global days of action and carnivalized politics in the present. Social Movement Studies, 7(2), 167-190.

Stone, A. L. (2009). More than adding a T: American lesbian and gay activists' attitudes towards transgender inclusion. Sexualities, 12(3), 334-354.

Strachan, E., \& Staples, B. (2012). Masturbation. Pediatrics in Review, 33(4), 190-191.

Strelan, P., Mehaffey, S. J., \& Tiggemann, M. (2003). Self-objectification and esteem in young women: The mediating role of reasons for exercise. Sex Roles, 48(1-2), 89-95.

Stryker, S. (1994). My words to Victor Frankenstein above the village of Chamounix: Performing transgender rage. GLQ, 1(3), 227-254. 
Stryker, S., \& Whittle, S. (2006). The transgender studies reader. New York: Taylor \& Francis.

Swank, E., \& Fahs, B. (2013). An intersectional analysis of gender and race for sexual minorities who engage in gay and lesbian rights activism. Sex Roles, 68(11-12), 660-674.

Taylor, V., \& Rupp, L. J. (2004). Chicks with dicks, men in dresses: What it means to be a drag queen. Journal of Homosexuality, 46(3-4), 113-133.

Thompson, L. (1999). The wandering womb: A cultural history of outrageous beliefs about women. Amherst: Prometheus Books.

Thorne, B. (1993). Gender play: Girls and boys in school. New Brunswick: Rutgers University Press.

Tiefer, L. (2006). Female sexual dysfunction: A case study of disease mongering and activist resistance. PLoS Medicine, 3(4), e178.

Tiefer, L. (2008). Female genital cosmetic surgery: Freakish or inevitable? Analysis from medical marketing, bioethics, and feminist theory. Feminism \& Psychology, 18(4), 466-479.

Tiggemann, M. (2004). Body image across the adult lifespan: Stability and change. Body Image, 1(1), 29-41.

Tiggemann, M., Martins, Y., \& Churchett, L. (2008). Beyond muscles: Unexplored parts of men's body image. Journal of Health Psychology, 13(8), 1163-1172.

Toerien, M., Wilkinson, S., \& Choi, P. Y. L. (2005). Body hair removal: The "mundane" production of normative femininity. Sex Roles, 52(5-6), 399-406.

Tolman, D. L. (1994). Doing desire: Adolescent girls' struggle for/with sexuality. Gender \& Society, 8(3), 324-342.

Tolman, D. L. (2002). Dilemmas of desire: Teenage girls talk about sexuality. Cambridge: Harvard University Press.

Vannier, S. A., \& O’Sullivan, L. F. (2010). Sex without desire: Characteristics of occasions of sexual compliance in young adults' committed relationships. Journal of Sex Research, 47(5), 429-439.

Vares, T. (2009). Reading the 'sexy oldie': Gender, age(ing) and embodiment. Sexualities, 12(4), 503-524.

Waite, L. J., \& Joyner, K. (2001). Emotional satisfaction and physical pleasure in sexual unions. Journal of Marriage and the Family, 63, 247-264.
Warner, M., \& Berland, L. (2000). Intimacy. Chicago: University of Chicago Press.

Weitz, R. (2001). Women and their hair: Seeking power through resistance and accommodation. Gender \& Society, 15(5), 667-686.

White, A. M. (1999). Talking feminist, talking Black: Micromobilization processes in a collective protest against rape. Gender \& Society, 13(1), 77-100.

Williams, C. J., Weinberg, M. S., \& Rosenberger, J. G. (2013). Trans men: Embodiments, identities, and sexualities. Sociological Forum, 28(4), 719-741.

Winter, S., Chalungsooth, P., Teh, Y. K., Rojanalert, N., Maneerat, K., Wong, Y. W., Macapagal, R. A., et al. (2009). Transpeople, transprejudice, and pathologization: A seven-country factor analytic study. International Journal of Sexual Health, 21(2), 96-118.

Wittig, M. (1992). The straight mind: And other essays. Boston: Beacon Press.

Woertman, L., \& Brink, F. (2012). Body image and female sexual functioning and behavior: A review. Journal of Sex Research, 49(2-3), 184-211.

Wong, Y. J., Horn, A. J., \& Chen, S. (2013). Perceived masculinity: The potential influence of race, racial essentialist beliefs, and stereotypes. Psychology of Men \& Masculinity, 14(4), 452-464.

Young, I. M. (1990). Pregnant embodiment: Subjectivity and alienation. In I. M. Young (Ed.), Throwing like a girl and other essays in feminist philosophy and social theory (pp. 160-176). Bloomington: Indiana University Press.

Young, I. (2005a). Breasted experience: The look and the feeling. In I. Young (Ed.), On female body experience: "Throwing like a girl" and other essays (pp. 75-96). New York: Oxford University Press.

Young, I. M. (2005b). On female body experience: Throwing like a girl and other essays. New York: Oxford University Press.

Zavella, P. (2008). Playing with fire? The gendered construction of Chicana/Mexican sexuality. In M. C. Gutmann, F. V. Matos Rodriguez, L. Stephen, \& P. Zavella (Eds.), Perspectives on Las Americas: A reader in culture, history, and representations (pp. 229-244). Malden: Blackwell Publishers. 